\title{
PENGARUH PROFITABILITAS, LIKUIDITAS, DAN RISIKO SISTEMATIS TERHADAP RETURN SAHAM PERUSAHAAN LQ45 TAHUN 2015-2019
}

\author{
Milka Prasetya Terutama ${ }^{1}$ \\ Universitas Katolik Parahyangan
}

\begin{abstract}
The purpose of investing in stocks is to get return in the form of capital gain and dividend. Before making an investment decision, investors and potential investors are expected to make an analysis. One of the analysis that can be done is fundamental analysis, financial reports is one of the most important source to do fundamental analysis. From financial reports, investors and potential investors can assess company's profitability and liquidity. In addition to return, investors and potential investors have to consider risks. Risk that arises from factors that are external to the organization is called systematic risk. The population used in this study is companies listed in LQ45 year 2015-2019. The sampling technique used is purposive sampling technique in order to obtain 25 samples of companies that met the research criteria. The type of data used is secondary data in the form of financial reports accessed through companies' websites, stock prices and dividends from Yahoo Finance, journals, and literature books. The data processing and analysis techniques used in this study are statistic descriptive, classical assumption tests, hypothesis testing which includes the $t$ statistical test and F statistical test. The results showed that partially, the variables of profitability, liquidity, and systematic risk cannot be stated to have an effect on stock return. Simultaneously, the variables of profitability, liquidity, and systematic risk cannot be stated to have an effect on stock return.
\end{abstract}

Keywords: profitability, liquidity, systematic risk, stock return, LQ45.

\begin{abstract}
ABSTRAK
Tujuan umum investor melakukan investasi saham adalah untuk memperoleh return yang terdiri dari capital gain dan dividen. Sebelum mengambil keputusan investasi, investor dan calon investor diharapkan melakukan analisis terlebih dahulu. Salah satu analisis yang dapat dilakukan adalah analisis fundamental, sumber informasi penting dalam analisis fundamental adalah laporan keuangan. Dari laporan keuangan, investor dan calon investor dapat menilai profitabilitas dan likuiditas perusahaan. Selain return, investor dan calon investor harus mempertimbangkan risiko. Risiko yang timbul akibat faktor lain di luar kendali perusahaan disebut dengan risiko sistematis. Populasi dalam penelitian ini adalah perusahaan yang terdaftar dalam LQ45 tahun 2015-2019. Teknik pengambilan sampel yang digunakan adalah teknik purposive sampling sehingga diperoleh 25 sampel perusahaan yang memenuhi kriteria penelitian. Jenis data yang digunakan adalah data sekunder berupa laporan keuangan yang diakses dari website perusahaan, data harga saham dan dividen dari Yahoo Finance, jurnal-jurnal referensi, dan buku literatur. Teknik pengolahan dan analisis data yang digunakan dalam penelitian ini adalah statistik deskriptif, uji asumsi klasik, pengujian hipotesis yang meliputi uji statistik t dan uji statistik F.

Hasil penelitian menunjukkan bahwa secara parsial, variabel profitabilitas, likuiditas, dan risiko sistematis tidak dapat dibuktikan berpengaruh terhadap return saham. Secara simultan, profitabilitas, likuiditas, dan risiko sistematis tidak dapat dibuktikan berpengaruh terhadap return saham.
\end{abstract}

Kata kunci: profitabilitas, likuiditas, risiko sistematis, return saham, LQ45.

Klasifikasi JEL: G1, G3, G4

1Jalan Rancabentang 1 no 10A, 081326180192, milkaprasetyaterutama@gmail.com 


\section{PENDAHULUAN}

Menurut Undang-Undang Nomor 8 Tahun 1995 Tentang Pasar Modal, pasar modal mempunyai peran yang strategis yaitu sebagai wadah pembiayaan bagi pengusaha yang membutuhkan dana dan wadah investasi bagi masyarakat. Berdasarkan data dari PT Kustodian Sentral Efek Indonesia (PT KSEI) jumlah Single Investor Identification (SID) yang tercatat pada akhir tahun 2019 adalah sebanyak 2.478.243, jumlah ini meningkat sekitar 580\% dalam 5 tahun dari posisi 364.465 pada akhir tahun 2014. Hal ini menunjukkan bahwa kegiatan investasi di pasar modal mulai diminati masyarakat.

Instrumen yang terkenal di pasar modal adalah saham. Tujuan investor dan calon investor melakukan investasi saham adalah untuk memperoleh return yang terdiri dari capital gain dan dividen. Sebelum mengambil keputusan investasi investor dan calon investor diharapkan melakukan analisis terlebih dahulu. Analisis tersebut dilakukan dengan tujuan untuk meminimalkan risiko. Analisis fundamental dapat dilakukan dengan melihat laporan keuangan perusahaan. Dari laporan keuangan, investor dan calon investor dapat menilai kinerja perusahaan menggunakan berbagai macam analisis.

Profitabilitas perusahaan merupakan hal yang perlu diperhatikan oleh investor dan calon investor dalam mengambil keputusan investasi. Profitabilitas adalah kemampuan suatu perusahaan dalam menghasilkan laba. Laba merupakan salah satu tujuan dari perusahaan (kecuali perusahaan nirlaba). Profitabilitas sangat penting karena perusahaan yang tidak dapat menghasilkan laba tidak akan dapat bertahan dalam jangka panjang (Johanns \& Hofstrand, 2019:1). Hasil penelitian yang dilakukan oleh Sepriana (2018) menunjukkan bahwa profitabilitas memiliki pengaruh terhadap return saham, sedangkan penelitian yang dilakukan oleh Febrioni (2016) menunjukkan bahwa profitabilitas tidak memiliki pengaruh terhadap return saham.

Dalam berinvestasi investor dan calon investor juga perlu mempertimbangkan likuiditas perusahaan. Likuiditas menunjukkan kemampuan perusahaan dalam memenuhi kewajiban jangka pendeknya. Jika perusahaan mampu memenuhi kewajiban jangka pendeknya maka keberlangsungan perusahaan tersebut tidak diragukan dan perusahaan tidak berisiko mengalami kebangkrutan (Subramanyam, 2014:544). Penelitian yang dilakukan oleh Parwati dan Sudiartha (2016) menunjukkan bahwa likuiditas berpengaruh terhadap return saham, sedangkan hasil penelitian Prabasari (2018) menunjukkan bahwa likuiditas tidak berpengaruh terhadap return saham.

Selain mempertimbangkan return dalam berinvestasi, investor dan calon investor juga harus mempertimbangkan risiko karena dua hal tersebut tidak dapat dipisahkan (Hartono, 2017:305). Risiko yang timbul akibat faktor lain di luar kendali perusahaan disebut dengan risiko sistematis. Penelitian yang dilakukan oleh Azhari, Suharti, dan Nurhayanti (2020) menunjukkan bahwa risiko sistematis memiliki pengaruh terhadap return saham, sebaliknya penelitian yang dilakukan oleh Habib (2016) menunjukkan bahwa risiko sistematis tidak memiliki pengaruh terhadap return saham.

Bursa Efek Indonesia mengembangkan dan menyediakan indeks saham yang dapat dimanfaatkan oleh pelaku pasar modal, salah satunya adalah indeks LQ45. Indeks LQ45 merupakan salah satu indeks yang paling awal diluncurkan oleh Bursa Efek Indonesia. Rata-rata return yang dihasilkan indeks LQ45 selama tahun 2015-2019 hanya 2,46\% per tahun, angka ini lebih rendah daripada rata-rata return IHSG yaitu 3,80\% per tahun. Padahal menurut Bursa Efek Indonesia (2019:9), indeks LQ45 berisi 45 saham perusahaan yang sudah disaring dengan kriteria-kriteria tertentu sehingga indeks tersebut berisi perusahaan yang sahamnya memiliki likuiditas tinggi, kapitalisasi pasar besar, dan fundamental baik. 
Berdasarkan latar belakang di atas, maka tujuan penelitian ini adalah: (1) mengetahui pengaruh profitabilitas terhadap return saham perusahaan yang terdaftar dalam indeks LQ45, (2) mengetahui pengaruh likuiditas terhadap return saham perusahaan yang terdaftar dalam indeks LQ45, (3) mengetahui pengaruh risiko sistematis terhadap return saham perusahaan yang terdaftar dalam indeks LQ45, (4) mengetahui pengaruh profitabilitas, likuiditas, dan risiko sistematis secara simultan terhadap return saham perusahaan yang terdaftar dalam indeks LQ45.

\section{TINJAUAN PUSTAKA}

\subsection{Profitabilitas}

Profitabilitas merupakan kemampuan perusahaan dalam menghasilkan laba. Profitabilitas sangat penting karena perusahaan yang tidak dapat menghasilkan laba tidak akan dapat bertahan dalam jangka panjang (Johanns \& Hofstrand, 2019:1). Kemampuan perusahaan dalam menghasilkan laba dapat diukur dengan rasio profitabilitas, rasio profitabilitas juga dapat mengukur tingkat efektivitas dan efisiensi manajemen suatu perusahaan dalam menghasilkan laba selama periode tertentu (Kasmir, 2016:197). Semakin besar profitabilitas maka semakin baik, artinya semakin besar kemampuan perusahaan dalam menghasilkan laba.

Profitabilitas dapat diukur dengan Return on Assets (ROA). Rasio ini menggambarkan sejauh mana tingkat pengembalian dari aset yang dimiliki perusahaan. Rasio ini dapat memberikan gambaran tentang tingkat efektivitas dan efisiensi perusahaan dalam mengelola aset yang dimilikinya untuk memperoleh laba selama suatu periode tertentu. Aset merupakan input yang digunakan perusahaan untuk menghasilkan output berupa laba perusahaan. Rumus untuk menghitung rasio ini adalah (Gitman, 2015:128):

$$
\text { Return on Assets }=\frac{\text { Earnings available for common stockholders }}{\text { Total assets }}
$$

\subsection{Likuiditas}

Likuiditas menunjukkan kemampuan perusahaan dalam memenuhi kewajiban jangka pendeknya. Jika perusahaan mampu memenuhi kewajiban jangka pendeknya maka keberlangsungan perusahaan tersebut tidak diragukan dan perusahaan tidak berisiko mengalami kebangkrutan (Subramanyam, 2014:544). Likuiditas sangat penting dalam operasi sehari-hari, tetapi aset seperti kas yang disimpan di bank dan surat berharga yang dapat dijual dalam waktu singkat biasanya memberikan tingkat pengembalian yang rendah, sehingga tidak baik jika perusahaan overinvest dalam likuiditas (Gitman, 2015:119).

Likuiditas dapat diukur dengan Current Ratio (CR). Rasio ini menunjukkan kemampuan perusahaan dalam melunasi kewajiban jangka pendeknya dengan aset lancarnya. Menurut Subramanyam (2014:546) rasio tersebut memiliki beberapa kelebihan yaitu dapat memberi gambaran current liability coverage (semakin besar aset lancar terhadap kewajiban jangka pendek, semakin besar keyakinan bahwa kewajiban jangka pendek akan dibayar), buffer against losses (semakin besar buffer maka semakin kecil risiko, current ratio menunjukkan margin of safety yang tersedia untuk menutupi penyusutan nilai aset lancar bukan kas), dan reserve of liquid funds (current ratio dapat mengukur margin of safety terhadap ketidakpastian arus kas perusahaan).Rumus untuk menghitung rasio ini adalah (Subramanyam, 2014:546):

$$
\text { Current Ratio }=\frac{\text { Curremt assets }}{\text { Current liabilities }}
$$

\subsection{Risiko Sistematis}


Risiko sistematis adalah risiko yang tidak dapat dihilangkan dengan diversifikasi dan disebabkan oleh faktor lain di luar kendali perusahaan. Risiko sistematis dapat diukur dengan beta. Hartono (2017:463) mendefinisikan beta sebagai pengukur volatilitas perubahan harga suatu saham terhadap perubahan harga pasar.

Risiko sistematis dapat diukur dengan beta pasar. Beta yang dihitung menggunakan data pasar berupa return sekuritas dan return pasar disebut beta pasar. Beta pasar didapat dengan dengan melakukan regresi perubahan return suatu saham dengan perubahan return pasar (Hartono, 2017:465).

Menurut Sandrasari (2010) faktor yang mempengaruhi volatilitas perubahan harga saham adalah volume perdagangan dan frekuensi perdagangan. Volume perdagangan adalah keseluruhan nilai transaksi pembelian maupun penjualan saham dalam mata uang. Frekuensi perdagangan adalah jumlah terjadinya transaksi penjualan dan pembelian saham.

\subsection{Return Saham}

Return adalah tujuan umum investor melakukan investasi dalam bentuk saham, return terdiri dari capital gain dan dividen. Menurut Atmaja dan Thomdean (2016:77) return saham dapat diukur dengan cara:

$$
\text { Return }=\frac{\left(\mathbf{P}_{1}-\mathbf{P}_{\mathbf{0}}\right)}{\mathbf{P}_{\mathbf{0}}}+\frac{\mathbf{D}_{\mathbf{1}}}{\mathbf{P}_{\mathbf{0}}}
$$

Keterangan:

$\mathrm{P}_{1}$ : harga saham pada tahun 1

$\mathrm{P}_{0}$ : harga saham pada tahun 0

$\mathrm{D}_{1}$ : dividen kas yang dibagikan pada tahun 0 sampai tahun 1

\subsubsection{Capital Gain/Loss}

Capital Gain/Loss merupakan salah satu faktor yang diperhitungkan dalam return saham. Capital Gain/Loss ini didapat dari perubahan harga saham pada tahun 0 ke tahun 1. Jika harga saham pada tahun 1 lebih tinggi daripada harga pada tahun 0 maka terjadi capital gain, sebaliknya jika harga saham pada tahun 1 lebih rendah daripada harga pada tahun 0 maka terjadi capital loss.

Mekanisme sistem perdagangan yang digunakan di Bursa Efek Indonesia adalah continuous auction system, yang artinya harga saham ditentukan oleh penawaran dan permintaan dari investor. Harga terbentuk jika ada pertemuan harga penawaran dan permintaan. Sistem lelang ini akan terus dilakukan selama jam kerja bursa sampai ditemukan harga kesepakatan (Hartono, 2017:161).

\subsubsection{Dividen}

Dividen yang dibagikan oleh perusahaan merupakan salah satu faktor yang diperhitungkan dalam return saham. Dividen adalah bagian dari laba perusahaan yang dibagikan kepada pemegang saham.

Kieso, Weygandt, dan Warfield $(2018,15-15)$ berpendapat bahwa terdapat beberapa hal yang menjadi pertimbangan perusahaan dalam mengambil kebijakan terkait pembagian dividen, yaitu:

1. Kebutuhan untuk menahan laba dalam bentuk aset sebagai proteksi atas kerugian yang mungkin terjadi (terkait dengan bond covenants).

2. Kebutuhan untuk menahan aset (yang sebenarnya dapat dibagikan dalam bentuk dividen) untuk membiayai pertumbuhan atau ekspansi pada tahun-tahun berikutnya. 
3. Kebutuhan untuk smooth out pembayaran dividen dari tahun ke tahun dengan cara mengakumulasi pendapatan di tahun yang baik agar dapat digunakan untuk membagikan dividen pada tahun yang kurang baik.

\subsection{Indeks LQ45}

Indeks LQ45 merupakan salah satu indeks tertua yang diluncurkan pada tanggal 1 Februari 1997. Indeks LQ45 adalah indeks yang mengukur kinerja harga dari 45 perusahaan dari berbagai macam sektor yang sahamnya memiliki likuiditas tinggi, kapitalisasi pasar besar, dan memiliki fundamental perusahaan yang baik (Bursa Efek Indonesia, 2019:9).

Faktor-faktor yang digunakan sebagai kriteria suatu perusahaan untuk dapat masuk dalam perhitungan indeks LQ45 adalah (Bursa Efek Indonesia, 2021):

1. Waktu tercatat di Bursa Efek Indonesia minimal 3 bulan

2. Aktivitas transaksi di pasar reguler (nilai, volume, dan frekuensi transaksi)

3. Jumlah hari perdagangan di pasar reguler

4. Kapitalisasi pasar

5. Keadaan keuangan dan prospek pertumbuhan perusahaan

Bursa Efek Indonesia (2020) dalam Siaran Pers No.064/BEI.SPR/07-2020 mengungkapkan bahwa indeks LQ45 diharapkan dapat menjadi acuan bagi investor untuk melihat pergerakan harga saham berdasarkan kriteria tersebut dan dapat menjadi dasar bagi manajer investasi untuk menerbitkan produk-produk investasi lainnya.

Bursa Efek Indonesia melakukan review terhadap Indeks LQ45 sebanyak empat kali dalam satu tahun, yaitu review mayor dan minor masing-masing dua kali. Review mayor dilakukan setiap bulan Januari dan Juli dengan tujuan untuk mengevaluasi konstituen indeks dan bobot yang digunakan untuk perhitungan indeks. Review minor dilakukan setiap bulan Mei dan November untuk mengevaluasi bobot indeks (Bursa Efek Indonesia, 2020).

\subsection{Penelitian Sebelumnya}

Berikut adalah penelitian serupa yang pernah dilakukan sebelumnya:

1. Penelitian yang dilakukan oleh Fransiska Sepriana pada tahun 2018 (Sepriana, 2018). Penelitian tersebut mengambil judul "Pengaruh Return on Assets, Return on Equity, Earning per Share, Price Book Value, dan Debt to Equity Ratio Terhadap Return Saham". Jumlah sampel yang digunakan adalah 33 perusahaan property dan real estate yang terdaftar di Bursa Efek Indonesia pada tahun 2012-2016. Hasil penelitian menunjukkan bahwa secara parsial profitabilitas berpengaruh terhadap return saham, sedangkan penilaian pasar dan solvabilitas tidak berpengaruh terhadap return saham. Secara simultan hasil penelitian menunjukkan profitabilitas, penilaian pasar, dan solvabilitas berpengaruh terhadap return saham.

2. Penelitian yang dilakukan oleh Rio Febrioni pada tahun 2016 (Febrioni, 2016). Penelitian tersebut mengambil judul "Pengaruh Return on Assets, Return on Equity, Earning per Share, dan Current Ratio Terhadap Return Saham". Jumlah sampel yang digunakan adalah 18 perusahaan yang terdaftar dalam LQ45 tahun 2011-2015. Hasil penelitian menunjukkan bahwa secara parsial likuiditas berpengaruh terhadap return saham, sedangkan profitabilitas tidak berpengaruh terhadap return saham. Secara simultan hasil penelitian menunjukkan profitabilitas dan likuiditas berpengaruh terhadap return saham.

3. Penelitian yang dilakukan oleh Ayu Dika Parwati dan Gede Mertha Sudiartha pada tahun 2016 (Parwati \& Sudiartha, 2016).

Penelitian tersebut mengambil judul "Pengaruh Profitabilitas, Leverage, Likuiditas dan Penilaian Pasar Terhadap Return Saham Pada Perusahaan Manufaktur”. Jumlah sampel yang 
digunakan adalah 35 perusahaan manufaktur yang terdaftar di Bursa Efek Indonesia pada tahun 2010-2014. Hasil penelitian menunjukkan bahwa secara parsial profitabilitas, leverage, likuiditas, dan penilaian pasar berpengaruh terhadap return saham. Secara simultan hasil penelitian menunjukkan profitabilitas, leverage, likuiditas, dan penilaian pasar berpengaruh terhadap return saham.

4. Penelitian yang dilakukan oleh Novia Tinci Prabasari pada tahun 2018 (Prabasari, 2018).

Penelitian tersebut mengambil judul "Pengaruh Likuiditas Terhadap Return Saham dan Profitabilitas Pada Perusahaan Property dan Real Estate yang Terdaftar di Bursa Efek Indonesia". Jumlah sampel yang digunakan adalah 39 perusahaan Property dan Real Estate yang terdaftar di Bursa Efek Indonesia pada tahun 2012-2016. Hasil penelitian menunjukkan bahwa likuiditas berpengaruh terhadap profitabilitas, namun likuiditas tidak berpengaruh terhadap return saham.

5. Penelitian yang dilakukan oleh Fauzan Azhari, Titing Suharti, dan Immas Nurhayanti pada tahun 2020 (Azhari, Suharti, dan Nurhayanti, 2020).

Penelitian tersebut mengambil judul "Pengaruh Beta Terhadap Return Saham Pada Perusahaan Sektor Perdagangan, Jasa, dan Investasi". Jumlah sampel yang digunakan adalah 10 perusahaan perdagangan, jasa, dan investasi yang terdaftar di Bursa Efek Indonesia pada tahun 2017 dan 2018. Hasil penelitian menunjukkan bahwa beta pasar berpengaruh terhadap return saham.

6. Penelitian yang dilakukan oleh Azwar Habib pada tahun 2016 (Habib, 2016).

Penelitian tersebut mengambil judul "Pengaruh Faktor Fundamental dan Risiko Sistematis Terhadap Return Saham Perusahaan Sektor Property di Bursa Efek Indonesia”. Jumlah sampel yang digunakan adalah 28 perusahaan Property yang terdaftar di Bursa Efek Indonesia pada tahun 2011-2014. Hasil penelitian menunjukkan bahwa profitabilitas berpengaruh terhadap return saham, sedangkan solvabilitas dan risiko sistematis tidak berpengaruh terhadap return saham. Secara simultan hasil penelitian menunjukkan profitabilitas, solvabilitas, dan risiko sistematis berpengaruh terhadap return saham.

\section{METODE DAN DATA}

\subsection{Metode Penelitian}

Pendekatan yang digunakan dalam penelitian ini adalah pendekatan ilmiah dengan menggunakan metode hypothetico-deductive. Metode hypothetico-deductive menyediakan pendekatan sistematis untuk menghasilkan pengetahuan yang dapat digunakan untuk memecahkan masalah (Sekaran \& Bougie, 2016:23).

\subsubsection{Jenis Penelitian}

Penelitian ini termasuk penelitian kausal, tujuan dari penelitian ini adalah untuk menguji apakah perubahan pada variabel (profitabilitas, likuiditas, risiko sistematis) menyebabkan perubahan pada variabel yang lain (return saham).

\subsubsection{Operasionalisasi Variabel}

Penelitian ini menggunakan dua jenis variabel, yaitu variabel dependen dan variabel independen.

\subsubsection{Variabel Dependen}

Variabel dependen dalam penelitian ini adalah return saham. Menurut Atmaja dan Thomdean (2016:77) return saham dapat diukur dengan cara sebagai berikut: 


$$
\text { Return }=\frac{\left(\mathbf{P}_{1}-\mathbf{P}_{0}\right)}{\mathbf{P}_{0}}+\frac{\mathbf{D}_{1}}{\mathbf{P}_{0}}
$$

Keterangan:

$\mathrm{P}_{1}$ : harga saham pada tahun 1

$\mathrm{P}_{0}$ : harga saham pada tahun 0

$\mathrm{D}_{1}$ : dividen kas yang dibagikan pada tahun 0 sampai tahun 1

Return saham berasal dari dua sumber yaitu dari capital gain (kenaikan harga saham) dan juga berasal dari dividen yang dibagikan oleh perusahaan. Harga saham yang digunakan adalah harga penutupan (closing price) akhir tahun. Dividen yang masuk dalam perhitungan adalah semua dividen kas yang dibagikan oleh perusahaan, baik dividen interim maupun dividen final.

\subsubsection{Variabel Independen}

Variabel independen yang digunakan dalam penelitian adalah:

a. Profitabilitas yang diukur dengan Return on Assets (ROA)

$$
\text { Return on Assets }=\frac{\text { Earnings available for common stockholders }}{\text { Total assets }}
$$

Sumber: Gitman (2015:130)

Rasio Return on Assets (ROA) dapat menggambarkan sejauh mana tingkat pengembalian dari aset yang dimiliki perusahaan. Rasio ini dapat memberikan gambaran tentang tingkat efektivitas dan efisiensi perusahaan dalam mengelola aset yang dimilikinya untuk memperoleh laba selama suatu periode tertentu (Gitman, 2015:130). Aset merupakan input yang digunakan perusahaan untuk menghasilkan output. Output tersebut berupa laba perusahaan.

b. Likuiditas yang diukur dengan Current Ratio (CR)

$$
\text { Current Ratio }=\frac{\text { Current assets }}{\text { Current liabilities }}
$$

Sumber: Subramanyam (2014:546)

Likuiditas umumnya diukur menggunakan Current Ratio (CR) karena rasio tersebut memiliki keunggulan yaitu dapat mengukur current liability coverage, buffer against losses, reserve of liquid funds (Subramanyam, 2014:546).

c. Risiko sistematis yang diukur dengan beta pasar

Menurut Atmaja dan Thomdean (2016:91) setiap saham memiliki volatilitas harga yang berbeda-beda. Saham dengan volatilitas tinggi memiliki karakteristik bila terjadi kenaikan harga maka kenaikan tersebut akan sangat tinggi, sebaliknya jika terjadi penurunan harga maka penurunan tersebut akan sangat dalam. Semakin tinggi volatilitas harga saham maka semakin tinggi risiko sistematisnya. Beta pasar merupakan pengukur volatilitas perubahan harga suatu saham terhadap perubahan harga pasar. Menurut Hartono (2017:467) beta pasar didapat dengan melakukan regresi perubahan harga suatu sekuritas dengan perubahan harga pasar. Dalam penelitian ini perubahan harga yang digunakan adalah perubahan harga harian. Perubahan harga pasar yang digunakan adalah perubahan harga IHSG karena merupakan indeks terbesar yang mengukur kinerja harga semua saham yang tercatat di Bursa Efek Indonesia.

\subsubsection{Data Penelitian}

Data yang digunakan dalam penelitian ini adalah data sekunder. Sekaran dan Bougie (2016:37) menjelaskan yang dimaksud dengan data sekunder adalah data yang telah ada sebelumnya atau 
dengan kata lain merupakan data yang tidak berasal langsung dari sumber utama. Data sekunder yang digunakan dalam penelitian ini diperoleh dari:

1. Laporan keuangan perusahaan yang terdaftar dalam LQ45 tahun 2014-2019 yang menjadi sampel penelitian. Data yang diambil adalah net income, aset lancar, total aset, liabilitas jangka pendek. Net income dan total aset digunakan untuk menghitung Return on Assets (ROA). Aset lancar dan liabilitas jangka pendek digunakan untuk menghitung Current Ratio (CR).

2. Website Yahoo Finance untuk mengambil data harga saham dan dividen. Harga saham yang diambil adalah harga penutupan akhir tahun 2014-2019 perusahaan yang menjadi sampel (untuk menghitung return), harga saham harian perusahaan yang menjadi sampel dan IHSG (untuk menghitung perubahan harga harian dalam mencari beta pasar), dividen yang diambil adalah dividen interim dan final yang digunakan untuk menghitung return.

3. Jurnal-jurnal referensi terkait profitabilitas, likuiditas, risiko sistematis, dan return saham dalam penelitian yang sudah ada.

4. Buku literatur yang berkaitan dengan profitabilitas, likuiditas, risiko sistematis, dan return saham.

\subsubsection{Teknik Pengumpulan Data dan Pengambilan Sampel Penelitian}

Teknik pengumpulan data yang digunakan dalam penelitian ini adalah studi pustaka dan dokumentasi data sekunder. Studi pustaka dilakukan untuk memperoleh pemahaman yang lebih mendalam mengenai permasalahan dalam penelitian. Dokumentasi data sekunder digunakan untuk memperoleh data yang digunakan untuk menghitung variabel dalam penelitian.

Populasi dalam penelitian ini adalah seluruh perusahaan yang terdaftar dalam indeks LQ45 yang dikeluarkan oleh Bursa Efek Indonesia tahun 2019 (tahun terakhir data penelitian) setelah evaluasi mayor (Agustus 2019), yang berjumlah 45 perusahaan.

Teknik pengambilan sampel yang digunakan dalam penelitian ini adalah teknik nonprobability sampling, yaitu purposive sampling. Purposive sampling merupakan teknik pemilihan anggota sampel berdasarkan kriteria yang telah ditetapkan. Kriteria yang ditetapkan untuk mengambil sampel dalam penelitian ini adalah sebagai berikut:

1. Perusahaan tidak termasuk dalam sektor perbankan. Menurut Surat Edaran Bank Indonesia No.6/ 23/DPNP, dalam mengukur kinerja dan tingkat kesehatan bank diperlukan matriks perhitungan khusus yang dikenal dengan model CAMELS.

2. Perusahaan membagikan dividen selama tahun 2015-2019.

3. Laporan keuangan perusahaan tahun 2015-2019 tersedia dan dapat diakses melalui website Bursa Efek Indonesia atau website resmi perusahaan.

4. Perusahaan tidak pernah mengalami suspensi selama tahun 2015-2019.

Berdasarkan kriteria yang telah ditetapkan, jumlah sampel yang digunakan dalam penelitian ini adalah sebanyak 25 perusahaan.

\subsubsection{Teknik Pengolah dan Analisis Data}

Data yang diambil dari laporan keuangan perusahaan dan website Yahoo Finance diolah sehingga menghasilkan rasio Return on Assets (ROA), Current Ratio (CR), beta pasar, dan return saham tahun 2015-2019. Olahan data tersebut kemudian dianalisis menggunakan bantuan program Statistical Product and Service Solutions (SPSS) versi 23.

\subsubsection{Statistik Deskriptif}

Ghozali (2016:19) mendefinisikan statistik deskriptif sebagai statistik yang menggambarkan atau mendeskripsikan data menjadi sebuah informasi yang lebih jelas dan mudah untuk dipahami. 
Statistik deskriptif memberikan gambaran suatu data melalui nilai rata-rata (mean), standar deviasi, maksimum, minimum, dan range.

\subsubsection{Uji Asumsi Klasik}

Uji asumsi klasik yang dilakukan dalam penelitian ini adalah sebagai berikut:

1. Uji Normalitas

Menurut Ghozali (2016:154) tujuan dari uji normalitas adalah untuk menguji apakah variabel pengganggu atau residual berdistribusi normal. Uji normalitas dapat dilakukan dengan analisis statistik. Analisis statistik dalam penelitian ini menggunakan uji statistik non parametrik Kolmogorov-Smirnov (K-S) dengan nilai signifikansi sebesar 0,05. Menurut Sekaran dan Bougie (2016:21) penelitian social science biasanya menggunakan nilai signifikansi 0,05. Dasar pengambilan keputusan dalam uji statistik ini adalah:

1. Jika nilai Asymp.Sig (2-tailed) $>$ dari 0,05, maka data terdistribusi normal.

2. Jika nilai Asymp.Sig (2-tailed) $\leq 0,05$, maka data tidak terdistribusi normal.

2. Uji Multikolinearitas

Menurut Ghozali (2016:103) tujuan dari uji multikolinearitas adalah untuk menguji apakah terdapat korelasi antar variabel bebas. Variabel yang saling berkorelasi adalah variabel yang tidak ontogonal, yaitu variabel independen yang nilai korelasi antar sesama variabelnya sama dengan nol.

Ghozali (2016:103) menjelaskan bahwa terdapat beberapa cara untuk mendeteksi multikolinearitas dalam model regresi, salah satunya adalah dengan melihat nilai tolerance dan VIF (Variance Inflation Factor). Ukuran tersebut menunjukkan variabel independen manakah yang dijelaskan oleh variabel independen lainnya. Tolerance mengukur variabilitas variabel independen yang tidak dijelaskan variabel independen lainnya. VIF $=1 /$ Tolerance, sehingga nilai tolerance yang rendah sama dengan nilai VIF yang tinggi. Dasar pengambilan keputusan dalam uji statistik ini adalah:

a. Jika nilai tolerance $\leq 0,10$ atau VIF $\geq 10$, maka dapat disimpulkan bahwa terdapat multikolinearitas dalam model regresi.

b. Jika nilai tolerance $>0,10$ atau VIF $<10$, maka dapat disimpulkan bahwa tidak terdapat multikolinearitas dalam model regresi.

3. Uji Autokorelasi

Menuruh Ghozali (2016:108) tujuan dari uji autokorelasi adalah untuk menguji apakah dalam model regresi terdapat korelasi antara kesalahan pengganggu pada periode 1 dengan periode 0 (sebelumnya). Masalah autokorelasi muncul jika terjadi korelasi, hal tersebut dapat terjadi karena observasi yang berurutan sepanjang waktu berkaitan satu dengan yang lainnya. Autokorelasi sering ditemukan pada data time series. Penelitian ini menggunakan tes Durbin Watson (DW test) untuk mendeteksi autokorelasi. Hipotesis yang akan diuji dalam penelitian ini adalah:

$\mathrm{H}_{0}$ : tidak ada autokorelasi $(\mathrm{r}=0)$

$\mathrm{H}_{\mathrm{A}}$ : ada autokorelasi $(\mathrm{r} \neq 0)$

Tabel 1

Pengambilan Keputusan Uji Autokorelasi

\begin{tabular}{|l|c|c|}
\hline \multicolumn{1}{|c|}{ Hipotesis nol } & Keputusan & Jika \\
\hline $\begin{array}{l}\text { Tidak ada autokorelasi } \\
\text { positif }\end{array}$ & Tolak & $0<\mathrm{d}<\mathrm{dl}$ \\
\hline
\end{tabular}




\begin{tabular}{|l|c|c|}
\hline $\begin{array}{l}\text { Tidak ada autokorelasi } \\
\text { positif }\end{array}$ & No decision & $\mathrm{dl} \leq \mathrm{d} \leq \mathrm{du}$ \\
\hline $\begin{array}{l}\text { Tidak ada korelasi } \\
\text { negatif }\end{array}$ & Tolak & $4-\mathrm{dl}<\mathrm{d}<4$ \\
\hline $\begin{array}{l}\text { Tidak ada korelasi } \\
\text { negatif }\end{array}$ & No decision & 4 - $\mathrm{du} \leq \mathrm{d} \leq 4-\mathrm{dl}$ \\
\hline $\begin{array}{l}\text { Tidak ada autokorelasi, } \\
\text { positif atau negatif }\end{array}$ & Tidak ditolak & $\mathrm{du}<\mathrm{d}<4$-du \\
\hline
\end{tabular}

Sumber: Ghozali (2016:108)

\section{Uji Heteroskedastisitas}

Menurut Ghozali (2016:134) tujuan dari uji heteroskedastisitas apakah dalam model regresi terjadi ketidaksamaan variance dari residual satu pengamatan ke pengamatan lainnya. Heteroskedastisitas terjadi jika variance dari residual satu pengamatan ke pengamatan yang lain berbeda. Penelitian ini menggunakan Uji Glejser untuk menemukan adanya heteroskedastisitas dengan cara meregresi nilai absolut residual terhadap variabel independen. Jika secara statistik variabel independen mempengaruhi variabel dependen. Dasar pengambilan keputusan untuk hal tersebut adalah sebagai berikut:

a. Jika probabilitas signifikansi (Sig) variabel independen lebih kecil sama dengan 0,05 , maka terjadi heteroskedastisitas.

b. Jika probabilitas signifikansi (Sig) variabel independen lebih besar dari 0,05, maka tidak terjadi heteroskedastisitas.

\subsubsection{Pengujian Hipotesis}

Hipotesis dalam penelitian ini adalah:

$\mathrm{H}_{01} \quad$ : Profitabilitas perusahaan tidak berpengaruh terhadap return saham.

$\mathrm{H}_{\mathrm{a} 1} \quad$ : Profitabilitas perusahaan berpengaruh terhadap return saham.

$\mathrm{H}_{02}$ : Likuiditas perusahaan tidak berpengaruh terhadap return saham.

$\mathrm{H}_{\mathrm{a} 2}$ : Likuiditas perusahaan berpengaruh terhadap return saham.

$\mathrm{H}_{03} \quad$ : Risiko sistematis tidak berpengaruh terhadap return saham.

$\mathrm{H}_{\mathrm{a} 3} \quad$ : Risiko sistematis berpengaruh terhadap return saham.

$\mathrm{H}_{04}$ : Profitabilitas, likuiditas, dan risiko sistematis perusahaan secara bersama-sama tidak berpengaruh terhadap return saham.

$\mathrm{H}_{\mathrm{a} 4}$ : Profitabilitas, likuiditas, dan risiko sistematis perusahaan secara bersama-sama berpengaruh terhadap return saham.

Penelitian ini menggunakan uji statistik $\mathrm{t}$, uji statistik $\mathrm{F}$ untuk melakukan pengujian hipotesis. Menurut Sekaran dan Bougie (2016:21) penelitian social science biasanya menggunakan nilai signifikansi 0,05 , sehingga penelitian ini menggunakan nilai signifikansi 0,05 .

1. Uji statistik $\mathrm{t}$

Menurut Ghozali (2016:97) uji statistik t dilakukan dengan tujuan untuk mengetahui pengaruh variabel independen terhadap variabel dependen secara parsial. Dasar hipotesis dan pengambilan keputusan dalam uji statistik t yaitu:

a. $H_{0}: \beta_{1}=0 ; H_{0}: \beta_{2}=0 ; H_{0}: \beta_{3}=0$, variabel independen tidak memiliki pengaruh terhadap variabel dependen secara parsial. Hal tersebut berarti profitabilitas, likuiditas, dan risiko sistematis secara parsial tidak memiliki pengaruh terhadap return.

b. $H_{A}: \beta_{1} \neq 0 ; H_{0}: \beta_{2} \neq 0 ; H_{0}: \beta_{3} \neq 0$, variabel independen memiliki pengaruh terhadap variabel dependen secara parsial. Hal tersebut berarti profitabilitas, likuiditas, dan risiko sistematis secara parsial memiliki pengaruh terhadap return.

c. Pengambilan keputusan: 
1) Jika nilai signifikansi t statistik $>0,05$ maka $\mathrm{H}_{0}$ diterima dan $\mathrm{H}_{A}$ ditolak. Hal ini berarti variabel independen secara parsial tidak berpengaruh terhadap variabel dependen.

2) Jika nilai signifikansi t statistik $<0,05$ maka $\mathrm{H}_{0}$ ditolak dan $\mathrm{H}_{\mathrm{A}}$ diterima. Hal ini berarti variabel independen secara parsial berpengaruh terhadap variabel dependen.

2. Uji statistik $F$

Menurut Ghozali (2016:96) uji statistik F bertujuan untuk mengetahui apakah semua variabel independen memiliki pengaruh secara simultan atau bersama-sama terhadap variabel dependen. Dasar hipotesis dan pengambilan keputusan dalam uji statistik F yaitu:

a. $H_{0}: \beta_{1}=\beta_{2}=\beta_{3}=0$, artinya variabel independen secara bersama-sama tidak berpengaruh terhadap variabel dependen. Dalam penelitian ini, hal tersebut menandakan bahwa profitabilitas, likuiditas, risiko sistematis secara bersama-sama tidak berpengaruh terhadap return.

b. $H_{\mathrm{A}}: \beta_{1} \neq \beta_{2} \neq \beta_{3} \neq 0$, artinya variabel independen secara bersama-sama berpengaruh terhadap variabel dependen. Dalam penelitian ini, hasil yang demikian menandakan bahwa profitabilitas, likuiditas, risiko sistematis secara bersama-sama berpengaruh terhadap return.

c. Pengambilan keputusan dilakukan sebagai berikut:

1) Jika nilai signifikansi $F$ statistik $>0,05$ maka $\mathrm{H}_{0}$ diterima dan $\mathrm{H}_{\mathrm{A}}$ ditolak. Hal ini berarti variabel independen secara bersama-sama tidak berpengaruh terhadap variabel dependen.

2) Jika nilai signifikansi $F$ statistik $<0,05$ maka $H_{0}$ ditolak dan $H_{A}$ diterima. Hal ini berarti variabel independen secara bersama-sama berpengaruh terhadap variabel dependen.

\section{Pembahasan}

\subsubsection{Statistik Deskriptif}

Hasil pengujian statistik deskriptif penelitian ini adalah sebagai berikut.

Tabel 2

Hasil Statistik Deskriptif

\begin{tabular}{|l|r|r|r|r|r|}
\hline & N & Min. & Max. & Mean & $\begin{array}{c}\text { Std. } \\
\text { Deviation }\end{array}$ \\
\hline Profitabilitas (X1) & 125 &,- 011 &, 460 &, 11469 &, 104012 \\
Likuiditas (X2) & 125 &, 280 & 6,567 & 2,07841 & 1,232794 \\
Risiko Sistematis (X3) & 125 &,- 894 & 3,201 & 1,17241 &, 487231 \\
Return (Y) & 125 &,- 612 & 2,374 &, 08337 &, 505342 \\
Valid N (listwise) & 125 & & & & \\
\hline
\end{tabular}

Sumber: Hasil pengolahan data SPSS 23

Berdasarkan Tabel 2, variabel profitabilitas yang diukur dengan Return on Assets (ROA) memiliki nilai rata-rata atau mean sebesar $11,47 \%$. Nilai tertinggi dari variabel profitabilitas adalah sebesar $46 \%$ yang dimiliki oleh LPPF pada tahun 2015. Sedangkan nilai terendah variabel profitabilitas adalah sebesar $-1,1 \%$ yang dimiliki oleh MNCN pada tahun 2015. Standar deviasi variabel profitabilitas adalah sebesar 0,104 , nilai tersebut lebih kecil dari nilai mean sehingga dapat dikatakan data profitabilitas dalam penelitian ini tidak terlalu bervariasi. 
Pada variabel likuiditas yang diukur dengan Current Ratio (CR) nilai rata-rata yang didapatkan adalah sebesar 207,84\%. Nilai tertinggi variabel likuiditas adalah sebesar $656,7 \%$ yang dimiliki oleh HMSP pada tahun 2015. Sedangkan nilai terendah variabel likuiditas adalah sebesar 28\% yang dimiliki oleh JSMR pada tahun 2019. Standar deviasi variabel likuiditas adalah sebesar 1,233, nilai tersebut lebih kecil dari nilai mean sehingga dapat dikatakan data likuiditas dalam penelitian ini tidak terlalu bervariasi.

Variabel risiko sistematis yang diukur dengan beta pasar memiliki nilai rata-rata sebesar 1,172. Nilai tertinggi variabel risiko sistematis adalah 3,201 yang dimiliki oleh SRIL pada tahun 2019. Sedangkan nilai terendah variabel risiko sistematis adalah -0,894 yang dimiliki oleh ITMG pada tahun 2019. Standar deviasi variabel risiko sistematis adalah 0,487, nilai tersebut lebih kecil dari nilai mean sehingga dapat dikatakan data risiko sistematis dalam penelitian ini tidak terlalu bervariasi.

Pada variabel return saham nilai rata-rata yang didapatkan adalah sebesar 8,34\%. Nilai tertinggi variabel return saham adalah sebesar 237,4\% yang dimiliki oleh ADRO pada tahun 2016. Sedangkan nilai terendah variabel return saham adalah sebesar $-61,2 \%$ yang dimiliki oleh PTBA pada tahun 2015. Standar deviasi variabel return saham adalah 0,505, nilai tersebut lebih besar dari nilai mean sehingga dapat dikatakan data return saham dalam penelitian ini cukup bervariasi.

\subsubsection{Uji Asumsi Klasik}

Berikut merupakan hasil uji asumsi klasik:

Tabel 3

Hasil One-Sample Kolmogorov-Smirnov

\begin{tabular}{|ll|r|}
\hline & & $\begin{array}{c}\text { Unstandardized } \\
\text { Residual }\end{array}$ \\
\hline $\mathrm{N}$ & Mean & 118 \\
& Std. Deviation &, 0000000 \\
Most Extreme Differences & Absolute &, 27993667 \\
& Positive &, 063 \\
& Negative &, 063 \\
Test Statistic & &,- 046 \\
Asymp. Sig. (2-tailed) & &, 063 \\
\hline
\end{tabular}

Sumber: Hasil pengolahan data SPSS 23

Dapat dilihat dari Tabel 3, bahwa nilai dari Asymp. Sig. (2-tailed) adalah 0,200, telah melebihi tingkat signifikansi 0,05 sebagai syarat data berdistribusi normal. Dapat disimpulkan bahwa uji normalitas terpenuhi.

Tabel 4

Hasil Uji Multikolinearitas

\begin{tabular}{|l|r|r|r|r|r|r|r|}
\hline \multirow{2}{*}{ Model } & \multicolumn{2}{|c|}{$\begin{array}{c}\text { Unstandardized } \\
\text { Coefficients }\end{array}$} & $\begin{array}{c}\text { Standardized } \\
\text { Coefficients }\end{array}$ & $\mathrm{t}$ & \multicolumn{2}{|c|}{ Sig. } & \multicolumn{2}{|c|}{ Collinearity Statistics } \\
\cline { 2 - 8 } & \multicolumn{1}{c|}{ B } & Std. Error & Beta & & & Tolerance & VIF \\
\hline $\begin{array}{l}\text { Profitabilitas } \\
\text { (X1) }\end{array}$ &, 209 &, 251 &, 079 &, 829 &, 409 &, 960 & 1,041 \\
\hline
\end{tabular}




\begin{tabular}{|l|r|r|r|r|r|r|r|} 
Likuiditas (X2) &, 005 &, 022 &, 021 &, 219 &, 827 &, 951 & 1,052 \\
Risiko &,- 013 &, 053 &,- 023 &,- 245 &, 807 &, 973 & 1,028 \\
sistematis (X3) & & & & & & & \\
\hline
\end{tabular}

Sumber: Hasil pengolahan data SPSS 23

Berdasarkan Tabel 4, dapat dilihat bahwa nilai tolerance untuk semua variabel independen lebih dari 0,1. Nilai VIF dari seluruh variabel independen bernilai kurang dari 10. Dari hasil perhitungan nilai tolerance dan VIF tiga variabel independen tersebut, dapat disimpulkan bahwa tidak terdapat multikolinearitas dalam model regresi.

Tabel 5

Hasil Uji Durbin-Watson

\begin{tabular}{|l|c|r|r|r|r|}
\hline Model & $\mathrm{R}$ & R Square & \multicolumn{1}{|c|}{$\begin{array}{c}\text { Adjusted R } \\
\text { Square }\end{array}$} & $\begin{array}{c}\text { Std. Error of the } \\
\text { Estimate }\end{array}$ & Durbin-Watson \\
\hline 1 &, $089^{\mathrm{a}}$ &, 008 &,- 018 &, 283596 & 2,093 \\
\hline
\end{tabular}

Sumber: Hasil pengolahan data SPSS 23

Hasil Durbin-Watson pada Tabel 5 adalah 2,093, nilai tersebut berada di antara dU dan 4dU sehingga dapat disimpulkan bahwa tidak terdapat autokorelasi dalam model regresi.

Tabel 6

Hasil Uji Glesjer

\begin{tabular}{|l|r|r|r|r|r|}
\hline \multirow{2}{*}{ Model } & \multicolumn{2}{|c|}{$\begin{array}{c}\text { Unstandardized } \\
\text { Coefficients }\end{array}$} & $\begin{array}{c}\text { Standardized } \\
\text { Coefficients }\end{array}$ & \multicolumn{1}{c|}{$\mathrm{t}$} \\
\cline { 2 - 6 } & \multicolumn{1}{|c|}{$\mathrm{B}$} & Std. Error & \multicolumn{1}{c|}{ Beta } & &, 000 \\
\hline (Constant) &, 234 &, 050 & & 4,664 &, 792 \\
Profitabilitas (X1) &,- 041 &, 156 &,- 025 &,- 264 &, 784 \\
Likuiditas (X2) &, 004 &, 014 &, 026 &, 275 &, 637 \\
Risiko sistematis (X3) &,- 016 &, 033 &,- 045 &,- 473 & \\
\hline
\end{tabular}

Sumber: Hasil pengolahan data SPSS 23

Dari hasil uji heteroskedastisitas pada Tabel 6, dapat dilihat bahwa seluruh nilai signifikansi (Sig.) variabel independen $>0,05$. Hal ini menunjukkan bahwa tidak terdapat heteroskedastisitas dalam model regresi atau terjadi kesamaan pada seluruh variance dari residual satu pengamatan ke pengamatan lain.

\subsubsection{Uji Hipotesis}

Penelitian ini menggunakan uji statistik $\mathrm{t}$ dan uji statistik F dengan tingkat confidence $95 \%$ untuk menguji hipotesis yang telah dibentuk sebelumnya.

Tabel 7

Hasil Uji t

\begin{tabular}{|l|r|r|r|r|r|}
\hline \multirow{2}{*}{ Model } & \multicolumn{2}{|c|}{$\begin{array}{c}\text { Unstandardized } \\
\text { Coefficients }\end{array}$} & $\begin{array}{c}\text { Standardized } \\
\text { Coefficients }\end{array}$ & $\mathrm{t}$ & Sig. \\
\cline { 2 - 6 } & $\mathrm{B}$ & Std. Error & Beta & & \\
\hline 1 (Constant) &,- 037 &, 081 & &,- 454 &, 651 \\
Profitabilitas (X1) &, 209 &, 251 &, 079 &, 829 &, 409
\end{tabular}




\begin{tabular}{|l|r|r|r|r|r|} 
Likuiditas (X2) &, 005 &, 022 &, 021 &, 219 &, 827 \\
Risiko sistematis (X3) &,- 013 &, 053 &,- 023 &,- 245 &, 807 \\
\hline
\end{tabular}

Sumber: Hasil pengolahan data SPSS 23

Berdasarkan Tabel 7, dapat dilihat bahwa variabel independen profitabilitas, likuiditas, dan risiko sistematis memiliki nilai signifikansi statistik t lebih besar dari 0,05. Hal ini menandakan bahwa $\mathrm{H}_{0}$ gagal untuk ditolak yang memiliki arti bahwa variabel independen profitabilitas, likuiditas, dan risiko sistematis secara parsial tidak dapat dibuktikan berpengaruh terhadap return saham.

Tabel 8

Hasil Uji F

\begin{tabular}{|ll|r|r|r|r|r|}
\hline \multicolumn{2}{|l|}{ Model } & Sum of Squares & df & Mean Square & $\mathrm{F}$ & Sig. \\
\hline 1 & Regression &, 073 & 3 &, 024 &, 304 &, $822^{\mathrm{b}}$ \\
& Residual & 9,169 & 114 &, 080 & & \\
& Total & 9,242 & 117 & & & \\
\end{tabular}

Sumber: Hasil pengolahan data SPSS 23

Berdasarkan Tabel 8, dapat dilihat bahwa nilai signifikansi $\mathrm{F}$ adalah sebesar 0,822, yaitu lebih besar dari tingkat signifikansi 0,05 . Hal ini menunjukkan bahwa $\mathrm{H}_{0}$ gagal untuk ditolak yang memiliki arti bahwa ketiga variabel independen yaitu profitabilitas, likuiditas, dan risiko sistematis secara bersama-sama tidak dapat dibuktikan berpengaruh terhadap profitabilitas perusahaan.

\subsection{Pembahasan Hasil Penelitian}

Subbab ini akan membahas lebih dalam mengenai hasil penelitian dari pengaruh profitabilitas, likuiditas, dan risiko sistematis terhadap return saham perusahaan yang terdaftar dalam LQ45 tahun 2015-2019 secara parsial maupun secara simultan.

\subsubsection{Pengaruh Profitabilitas terhadap Return Saham}

Hasil penelitian menggunakan uji statistik t melalui program SPSS 23 menunjukkan nilai signifikansi statistik $t$ untuk profitabilitas adalah sebesar 0,409, lebih besar dari tingkat signifikansi 0,05. Hal tersebut menunjukkan bahwa profitabilitas yang diukur dengan Return on Assets (ROA) tidak dapat dibuktikan berpengaruh terhadap return saham.

Salah satu faktor yang diperhitungkan dalam return saham adalah capital gain/loss yang berasal dari perubahan harga saham. Mekanisme pergerakan harga saham dipengaruhi oleh perilaku/keputusan investor dalam melakukan penjualan dan pembelian saham. Keputusan tersebut dipengaruhi oleh berbagai macam faktor dan sudut pandang. Hasil penelitian ini dapat diartikan bahwa investor tidak melihat Return on Assets (ROA) dalam mengambil keputusan investasi.

Profitabilitas yang diukur dengan Return on Assets (ROA) dihitung berdasarkan data historis yang menggambarkan kondisi masa lalu, sedangkan investor lebih mementingkan prospek perusahaan di masa yang akan datang.

Faktor lainnya adalah perusahaan-perusahaan yang terdaftar dalam LQ45 memiliki karakteristik yang serupa, salah satunya adalah perusahaan yang berfundamental baik. Indeks LQ45 diciptakan oleh Bursa Efek Indonesia untuk memudahkan investor dalam mengambil keputusan investasi. Keputusan investasi terkadang diambil dengan cepat, dengan adanya indeks 
LQ45 terkadang investor tidak melihat laporan keuangan ataupun kinerja keuangan (dalam hal ini yaitu profitabilitas yang diukur dengan Return on Assets) dengan seksama sebelum mengambil keputusan investasi karena menganggap bahwa perusahaan yang terdaftar dalam LQ45 pasti memiliki kinerja yang baik.

Dalam menghitung return saham salah satu faktor yang diperhitungkan adalah dividen. Profitabilitas yang diukur dengan Return on Assets (ROA) menunjukkan kemampuan perusahaan dalam menghasilkan laba, tetapi perusahaan yang mampu menghasilkan laba belum tentu membagikan dividen yang besar, bahkan perusahaan dapat memilih untuk tidak membagikan dividen.

Hal tersebut disebabkan karena perusahaan perlu mempertimbangkan banyak hal dalam mengambil kebijakan pembagian dividen, seperti ada tidaknya keperluan untuk menahan laba dalam bentuk aset sebagai proteksi atas kerugian yang mungkin terjadi (terkait dengan bond covenants), untuk membiayai pertumbuhan atau rencana ekspansi perusahaan pada tahun-tahun berikutnya sehingga laba tidak dibagikan, dan kebutuhan untuk smooth out pembayaran dividen dari tahun ke tahun dengan cara mengakumulasi pendapatan di tahun yang baik agar dapat digunakan untuk membagikan dividen pada tahun yang kurang baik (Kieso, Weygandt, \& Warfiled, 2018:15-15).

Hasil penelitian ini sesuai dengan penelitian sebelumnya yang telah dilakukan oleh Febrioni (2016) yang menyatakan bahwa profitabilitas yang diukur dengan Return on Assets (ROA) tidak dapat dibuktikan berpengaruh terhadap return saham.

\subsubsection{Pengaruh Likuiditas terhadap Return Saham}

Hasil penelitian menggunakan uji statistik t melalui program SPSS 23 menunjukkan nilai signifikansi statistik t untuk likuiditas adalah sebesar 0,827, lebih besar dari tingkat signifikansi 0,05. Hal tersebut menunjukkan bahwa likuiditas yang diukur dengan Current Ratio (CR) tidak dapat dibuktikan berpengaruh terhadap return saham.

Hasil penelitian tersebut dapat diartikan bahwa investor tidak mempertimbangkan likuiditas yang diukur dengan Current Ratio (CR) dalam mengambil keputusan investasi. Perusahaan-perusahaan yang terdaftar di LQ45 merupakan perusahaan yang berfundamental baik, sehingga investor tidak perlu ragu terkait keberlangsungan usaha dan risiko kebangkrutan perusahaan yang terdaftar dalam LQ45.

Semakin tinggi likuiditas artinya semakin mampu perusahaan tersebut melunasi kewajiban jangka pendeknya, namun tidak dapat diartikan bahwa semakin tinggi likuiditas maka semakin baik kondisi perusahaan dan sebaliknya semakin rendah likuiditas semakin buruk kondisi perusahaan tersebut.

Likuiditas yang terlalu tinggi dapat dianggap tidak menguntungkan, hal ini disebabkan karena aset lancar seperti kas pada bank dan surat berharga jangka pendek biasanya tidak dapat memberikan imbal hasil yang tinggi (Gitman, 2015:119).

Di sisi lain, nilai likuiditas yang rendah juga tidak selalu mencerminkan kondisi perusahaan sedang buruk, UNVR adalah contoh perusahaan dalam objek penelitian yang memiliki Current Ratio (CR) di bawah satu selama lima tahun penelitian berturut-turut, namun UNVR terbukti tidak pernah mengalami isu kebangkrutan, bahkan UNVR berhasil meningkatkan laba.

Hal tersebut disebabkan karena UNVR merupakan perusahaan yang terus berkembang dengan pesat dan terus menerus melakukan inovasi, sehingga UNVR tidak ingin current assets yang dimilikinya menganggur terlalu besar. Dari laporan tahunan yang diterbitkan UNVR, dapat diketahui bahwa pada tahun 2015, 2016, dan 2017 UNVR menerima penghargaan internasional “The World's Most Innovative Companies" yang diberikan oleh Forbes. 
Nama baik yang dimiliki oleh UNVR mempengaruhi tingginya kepercayaan investor, sehingga investor tetap percaya bahwa UNVR akan mampu melunasi kewajibannya walaupun UNVR memiliki Current Ratio (CR) di bawah satu. Kepercayaan investor terhadap UNVR dapat dibuktikan dengan melihat bahwa selama lima tahun penelitian UNVR selalu masuk dalam sepuluh perusahaan dengan kapitalisasi pasar tertinggi di Bursa Efek Indonesia.

Nama baik UNVR dapat dibuktikan dengan banyaknya penghargaan baik nasional maupun internasional yang diterima setiap tahunnya. UNVR menerima penghargaan internasional "Asia's Best Companies" pada tahun 2017 yang diberikan oleh Finance Asia, serta penghargaan "Forbes Indonesia Best of the Best Award" pada tahun 2015, 2016, dan 2019 yang diberikan oleh Forbes.

Likuiditas yang rendah juga tidak menjamin manajemen lebih tidak leluasa dalam membagikan dividen karena likuiditas yang diukur dengan Current Ratio (CR) hanya melihat saldo titik waktu tertentu yaitu akhir tahun, tanpa melihat arus kas. UNVR terbukti tetap dapat membagikan dividen secara rutin selama lima tahun penelitian berturut-turut walaupun memiliki Current Ratio (CR) di bawah satu.

Hasil penelitian ini sesuai dengan hasil penelitian sebelumnya yang telah dilakukan oleh Prabasari (2018) yang menyatakan bahwa likuiditas tidak berpengaruh terhadap return saham.

\subsubsection{Pengaruh Risiko Sistematis terhadap Return Saham}

Hasil penelitian menggunakan uji statistik t melalui program SPSS 23 menunjukkan nilai signifikansi statistik t untuk risiko sistematis adalah sebesar 0,807, lebih besar dari tingkat signifikansi 0,05 . Hal tersebut menunjukkan bahwa risiko sistematis yang diukur dengan beta pasar tidak dapat dibuktikan berpengaruh terhadap return saham.

Beta pasar merupakan pengukur volatilitas perubahan harga suatu saham terhadap perubahan harga pasar. Saham dengan volatilitas tinggi memiliki karakteristik "High Risk, High Return". Jika terjadi kenaikan harga maka kenaikan tersebut akan sangat tinggi, sebaliknya jika terjadi penurunan harga maka penurunan tersebut akan sangat dalam.

Beta pasar diukur dengan cara meregresikan perubahan harga saham perusahaan terhadap perubahan harga IHSG secara harian selama tahun berjalan, rata-rata jumlah perubahan harga yang digunakan dalam regresi adalah 241 hari. Sedangkan capital gain/loss dalam return diukur dengan melihat harga saham hanya pada akhir tahun.

Selama 241 hari perdagangan tentunya terdapat banyak hal yang mempengaruhi volatilitas saham secara harian, namun hal tersebut belum tentu berpengaruh di akhir tahun. Sentimen yang ada pada saat-saat tertentu selama tahun berjalan dapat mempengaruhi volatilitas harian akibat respons pasar pada saat sentimen tersebut muncul, tetapi belum tentu sentimen yang sama tersebut memiliki dampak di akhir tahun.

Risiko sistematis menggambarkan volatilitas harga saham, dalam penelitian ini volatilias yang digunakan adalah volatilitas harian. Volatilitas secara harian juga dipengaruhi oleh para pelaku pasar yang melakukan aktivitas jual beli dalam waktu cepat, transaksi yang mereka lakukan biasanya bersifat jangka pendek. Hal ini mempengaruhi volatilitas harian sepanjang tahun berjalan ( 241 hari), tetapi hal tersebut tidak tergambarkan pada akhir tahun (1 hari, yaitu hari terakhir perdagangan).

Hari terakhir perdagangan (hari yang digunakan untuk mengukur return) memiliki karakter yang berbeda dengan hari-hari lainnya, kondisi pasar relatif konstan karena perusahaan biasanya tidak membuat kebijakan besar dan investor biasanya tidak melakukan perubahan besar dalam portofolio yang dikelolanya. Hal ini dapat dibuktikan dengan melihat volume perdagangan dan frekuensi perdagangan di Bursa Efek Indonesia tahun 2015-2019. Secara ratarata hari terakhir perdagangan memiliki volume perdagangan $56,86 \%$ lebih rendah daripada 
rata-rata volume perdagangan selama satu tahun berjalan dan memiliki frekuensi perdagangan 4,96\% lebih rendah daripada rata-rata frekuensi perdagangan selama satu tahun berjalan.

Hasil penelitian ini sesuai dengan hasil penelitian sebelumnya yang telah dilakukan oleh Habib (2016) yang menyatakan bahwa risiko sistematis tidak memiliki pengaruh terhadap return saham.

\subsubsection{Pengaruh Profitabilitas, Likuiditas, dan Risiko Sistematis terhadap Return Saham}

Hasil penelitian menggunakan uji statistik F melalui program SPSS 23 menunjukkan nilai dari signifikansi statistik $F$ adalah sebesar 0,822, lebih besar dari tingkat signifikansi 0,05. Hal tersebut menunjukkan bahwa profitabilitas, likuiditas, dan risiko sistematis secara simultan tidak dapat dibuktikan berpengaruh terhadap return saham.

Capital gain/loss dan dividen merupakan faktor yang diperhitungkan dalam return saham. Return saham perusahaan-perusahaan yang terdaftar dalam LQ45 lebih dipengaruhi oleh perubahan harganya daripada dividen (rata-rata dividend yield hanya 2,91\%). Perubahan harga saham sendiri dipengaruhi oleh keputusan penjualan dan pembelian yang dilakukan oleh pelaku pasar.

Keputusan penjualan dan pembelian bisa didasarkan oleh berbagai faktor lain, contohnya adalah faktor kualitatif dan nilai intrinsik (yang berhubungan dengan margin of safety). Berdasarkan artikel dari Yahoo Finance (2020), Warren Buffett yang dikenal sebagai salah satu investor terbaik di dunia mengungkapkan bahwa terdapat tiga tahapan yang dilakukan olehnya dan rekannya yaitu Charlie Munger dalam mengevaluasi sebuah bisnis dalam rangka investasi. Tahapan yang pertama adalah mencari bisnis yang memiliki moat, tahapan yang ke-dua adalah mengevaluasi apakah bisnis tersebut dapat bertahan lima sampai dua puluh tahun ke depan dan faktor penting apa saja yang dapat membuat perusahaan tersebut tetap bertahan, tahapan yang ke-tiga adalah mengevaluasi integritas dan kemampuan manajer perusahaan.

Dalam mengambil keputusan investasi Warren Buffett juga menganut konsep margin of safety, artinya Warren Buffett hanya membeli saham yang dapat memberikan margin of safety yang memadai (Brodersen \& Pysh, 2014:63).

Di luar analisis fundamental, banyak pelaku pasar yang menerapkan analisis lain yaitu analisis teknikal dalam mengambil keputusan penjualan dan pembelian saham. Analisis teknikal dilakukan menggunakan grafik yang merekam pergerakan harga dan volume transaksi untuk mengidentifikasi pola pergerakan harga yang terjadi di pasar tanpa melihat fundamental perusahaan (Ong, 2016:1).

Faktor lainnya adalah terkadang pelaku pasar tidak rasional dalam mengambil keputusan penjualan dan pembelian saham. Hal ini dibuktikan oleh Jeremy Siegel yang mempelajari 120 kenaikan dan penurunan besar pada pasar modal dan tidak menemukan penjelasan untuk $75 \%$ pergerakan di pasar modal. Banyak fenomena yang gagal dijelaskan oleh teori pasar modal efisien yang berasumsi harga saham mencerminkan informasi relevan sehingga saham tersebut dihargai secara "wajar". Fenomena tidak wajar ini lebih tepat dijelaskan dengan behavioral finance (Atmaja, 2018:50).

\section{SIMPULAN}

Berdasarkan hasil penelitian yang telah dilakukan mengenai pengaruh profitabilitas, likuiditas, dan risiko sistematis terhadap return saham perusahaan yang terdaftar dalam LQ45 tahun 20152019 maka dapat disimpulkan sebagai berikut: 
1. Profitabilitas tidak dapat dibuktikan berpengaruh terhadap return saham perusahaan yang terdaftar dalam LQ45 tahun 2015-2019. Hal ini dapat diartikan bahwa investor tidak melihat profitabilitas yang diukur dengan Return on Assets (ROA) dalam mengambil keputusan investasi karena Return on Assets (ROA) dihitung dari data historis sedangkan investor lebih mementingkan prospek masa depan perusahaan, investor menganggap bahwa perusahaan yang terdaftar dalam LQ45 pasti memiliki kinerja yang baik. Perusahaan juga belum tentu membagikan dividen lebih besar jika kemampuan mengelola aset untuk menghasilkan labanya lebih besar karena perusahaan perlu mempertimbangkan banyak hal dalam mengambil kebijakan pembagian dividen.

2. Likuiditas tidak dapat dibuktikan berpengaruh terhadap return saham perusahaan yang terdaftar dalam LQ45 tahun 2015-2019. Hal ini dapat diartikan bahwa investor tidak melihat likuiditas yang diukur dengan Current Ratio (CR) karena menganggap bahwa perusahaan yang terdaftar dalam LQ45 pasti memiliki kinerja yang baik sehingga investor tidak perlu ragu terkait keberlangsungan usaha dan risiko kebangkrutan perusahaan yang terdaftar dalam LQ45. Likuiditas yang juga tidak menjamin keleluasaan manajemen dalam membagikan dividen karena likuiditas yang diukur dengan Current Ratio (CR) hanya melihat saldo titik waktu tertentu yaitu akhir tahun, tanpa melihat arus kas.

3. Risiko sistematis tidak dapat dibuktikan berpengaruh terhadap return saham perusahaan yang terdaftar dalam LQ45 tahun 2015-2019. Risiko sistematis diukur dengan beta pasar harian, selama 241 hari perdagangan terdapat banyak hal yang mempengaruhi volatilitas saham secara harian, namun hal tersebut belum tentu berpengaruh di akhir tahun. Hari terakhir perdagangan memiliki karakter yang berbeda yaitu kondisi pasar relatif konstan.

4. Profitabilitas, likuiditas, dan risiko sistematis secara simultan tidak dapat dibuktikan berpengaruh terhadap return saham perusahaan yang terdaftar dalam LQ45 tahun 20152019. Keputusan penjualan dan pembelian saham bisa didasarkan oleh berbagai faktor dan jenis analisis lain, contohnya adalah faktor kualitatif, nilai intrinsik, dan analisis teknikal. Selain itu terkadang pelaku pasar tidak rasional dalam mengambil keputusan penjualan dan pembelian saham.

Implikasi hasil penelitian ini adalah:

1. Bagi investor dan calon investor

Sebelum mengambil keputusan penjualan dan pembelian saham, investor sebaiknya mempertimbangkan faktor kualitatif, menghitung nilai intrinsik sehingga dapat mengetahui margin of safety, serta dapat dilengkapi dengan analisis teknikal sebelum mengambil keputusan penjualan dan pembelian saham.

2. Bagi peneliti selanjutnya

Peneliti selanjutnya dapat menggunakan data penelitian yang lebih banyak, yaitu dengan menambah jumlah sampel atau tahun penelitian agar hasil penelitian lebih baik dan mampu menggambarkan keseluruhan populasi. Selain itu, peneliti selanjutnya dapat menggunakan indikator lain selain Return on Assets (ROA), Current Ratio (CR), dan beta pasar untuk mengukur profitabilitas, likuiditas, dan risiko sistematis. Peneliti selanjutnya juga dapat melakukan penelitian dengan sampel perusahaan yang terdaftar dalam indeks selain LQ45, seperti indeks BUMN20 agar dapat melihat apakah terdapat perbedaan hasil penelitian jika perusahaan yang digunakan adalah perusahaan milik negara. Peneliti selanjutnya juga dapat meneliti tentang behavioral finance yang dapat mempengaruhi investor dalam mengambil keputusan penjualan dan pembelian saham. 


\section{DAFTAR PUSTAKA}

Atmaja, L. S., \& Thomdean. (2015). Who Wants To Be A Smiling Investor. Jakarta: Kepustakaan Populer Gramedia.

Bank Indonesia. (2004, May 31). Bank Indonesia. Retrieved from BI: https://www.bi.go.id/id/archive/arsip-peraturan/Pages/ketentuan\%20perbankan.aspx

Brodersen, S., \& Pysh, P. (2014). Warren Buffett Accounting Book. Saxonburg: Pylon Publishing.

Bursa Efek Indonesia. (2020, July 24). Press Release. Retrieved from IDX: https://www.idx.co.id/berita/press-release-detail/?emitenCode $=1340$

F. A., Suharti, T., \& Nurhayanti, I. (2020). Pengaruh Beta Terhadap Return Saham Pada Perusahaan Sektor Perdagangan, Jasa dan Investasi. Jurnal Ilmu Manajemen, 509-519.

Febrioni, R. (2016). Pengaruh Return On Assets, Return On Equity, Earning Per Share, dan Current Ratio Terhadap Return Saham. e-Proceeding of Management, 3439.

Gitman, L. J. (2015). Principles of Managerial Finance. Harlow: Pearson Education Limited.

Graham, B., \& Zweig, J. (2019). The Intelligent Investor. Jakarta: PT Serambi Semesta Distribusi.

Habib, A. (2016). Pengaruh Faktor Fundamental dan Risiko Sistematik Terhadap Return Saham Perusahaan Sektor Property Di Bursa Efek Indonesia. Yogyakarta: Univesitas Negeri Yogyakarta.

Hartono, J. (2017). Teori Portofolio dan Analisis Investasi. Yogyakarta: BPFE-Yogyakarta.

Johanns, A., \& Hofstrand, D. (2019). Understanding Profitability. Retrieved from IOWA State University: https://www.extension.iastate.edu/agdm/wholefarm/pdf/c3-24.pdf

Kasmir. (2016). Analisis Laporan Keuangan. Jakarta: Raja Grafindo Persada.

Kieso, D. E., Weygandt, J. J., \& Warfield, T. D. (2018). Intermediate Accounting IFRS Edition. Singapore: Wiley.

Kustodian Sentral Efek Indonesia. (2019, Desember 30). Pencapaian KSEI Tahun 2019: Implementasikan Tonggak Sejarah Baru Pasar Modal Indonesia. Retrieved from KSEI: https://www.ksei.co.id/files/uploads/press_releases/press_file/id-

id/175_berita_pers_pencapaian_ksei_tahun_2019_implementasikan_tonggak_sejarah_bar u_pasar_modal_indonesia_20200123103744.pdf

Ong, E. (2016). Technical Analysis for Mega Profit. Jakarta: Gramedia Pustaka Utama. 
Parwati, R. A., \& Sudiartha, G. M. (2016). Pengaruh Profitabilitas, Leverage, Likuiditas dan Penilaian Pasar Terhadap Return Saham Pada Perusahaan Manufaktur. E-Jurnal Manajemen Unud, 385-413.

Pemerintah Republik Indonesia. (1985). Undang-Undang Nomor 8 Tahun 1995 Tentang Pasar Modal. Jakarta: Sekretariat Negara. Retrieved from Otoritas Jasa Keuangan: https://www.ojk.go.id/id/kanal/pasar-modal/regulasi/undangundang/Documents/Pages/undang-undang-nomor-8-tahun-1995-tentang-pasarmodal/UU\%20Nomor\%208\%20Tahun\%201995\%20(official).pdf

Prabasari, N. T. (2018). Pengaruh Likuiditas terhadap Return Saham dan Profitabilitas pada Perusahaan Property dan Real Estate yang Terdaftar di Bursa Efek Indonesia. Yogyakarta: Universitas Islam Indonesia.

Sandrasari, W. T. (2010). Analisis Pengaruh Volume Perdagangan, Frekuensi Perdagangan, dan Order Imbalance Terhadap Volatilitas Harga Saham Pada Perusahaan Go Public di Bursa Efek Indonesia. Surakarta: Universitas Sebelas Maret.

Sekaran, U., \& Bougie, R. (2016). Research Methods for Business. Chichester: John Wiley \& Sons.

Sepriana, F. (2018). Pengaruh Return On Assets (ROA), Return On Equity (ROE), Earning Per Share (EPS), Price Book Value (PBV), dan Debt To Equity Ratio (DER) Terhadap Return Saham. Undip e-journal, 1-9.

Subramanyam, K. (2014). Financial Statement Analysis. New York: McGraw Hill Education.

Unilever Indonesia. (2018). Laporan Tahunan 2018: Bertransformasi untuk Masa Depan Berkelanjutan. Jakarta: Unilever Indonesia.

Yahoo Finance. (2020, February 6). Finance. Retrieved from Yahoo Finance: https://finance.yahoo.com/news/warren-buffett-explains-moat-principle164442359.html 